\author{
T. Стоянова, \\ кандидат юридичних наук, \\ доцент кафедри цивільного процесу \\ Національного університету «Одеська юридична академія» \\ I. Іліопол, \\ кандидат юридичних наук, \\ старший викладач кафедри цивільного процесу \\ Національного університету «Одеська юридична академія»
}

\title{
ТИЖДЕНЬ ЦИВІЛЬНОГО ПРОЦЕСУ В НАЦІОНАЛЬНОМУ УНІВЕРСИТЕТІ «ОДЕСЬКА ЮРИДИЧНА АКАДЕМІЯ»
}

У Національному університеті «Одеська юридична академія» за ініціативою завідувача кафедри цивільного процесу, доктора юридичних наук, професора Н.Ю. Голубєвої та професорсько-викладацького складу кафедри цивільного процесу з 8 по 12 квітня 2019 р. було проведено щорічний науково-творчий марафон «Тиждень цивільного процесу».

Ювілейний (у цьому році вже п'ятий) захід, що організовує кафедра цивільного процесу, ознаменувався професійними майстер-класами за участю досвідчених доцентів кафедри та запрошених практичних спеціалістів, конкурсом наукових робіт та неперевершеним фестивалем студентської творчості за участю творчого журі.

У заходах взяли участь викладачі, аспіранти та студенти різних факультетів університету, науковці з вищих навчальних закладів країни, юристи-практики - судді, адвокати, юрисконсульти, а також праведні вчені-процесуалісти України.

У перші три дні тижня цивільного процесу відбулася серія майстер-класів.

Тиждень цивільного процесу відкрив 8 квітня 2019 р. сумісний майстер-клас науковців та практиків на тему «Цивільно-правові аспекти повернення дитини (у світлі Гаазької конвенції)». Майстер-клас проводила кандидат юридичних наук, доцент T.A. Стоянова за участю начальника відділу судової роботи та міжнародного співробітництва Головного територіального управління юстиції в Одеській області К.В. Переверзової та головного спеціаліста відділу судової роботи та міжнародного співробітництва Головного територіального управління юстиції в Одеській області В.В. Донкоглової. Поєднання науково-доктринального погляду та практичного досвіду в майстер-класі стало цікавим досвідом для студентів та інших присутніх.

9 квітня 2019 р. доцент кафедри цивільного процесу I.O. Бут розповів про порядок звернення до Європейського суду з прав людини.

10 квітня 2019 р. яскраво й цікаво виступила кандидат юридичних наук, доцент кафедри цивільного процесу Л.А. Островська $з$ доповіддю «Протокол № 16 до Конвенції про захист прав людини і основоположних свобод: чи працюватиме він в Україні?».

11 квітня 2019 р. ознаменувалося декількома цікавими заходами. Було проведене модельне судове засідання «Зустрінемось у суді», організоване 
кафедрою цивільного процесу Національного університету «Одеська юридична академія» під керівництвом кандидата юридичних наук, доцента I.O. Бут разом із факультетом цивільної та господарської юстиції та Київським районним судом м. Одеси. Цей захід дав можливість студентам провести повноцінне судове засідання під керівництвом i 3 рекомендаціями суддів Київського районного суду м. Одеси. Атмосфера була настільки творчою, легкою, цікавою та продуктивною, що було вирішено проводити такий захід щомісяця.

На конкурс студентських наукових робіт студенти надали для анонімного професійного оцінювання роботи на цивільно-правову та цивільно-процесуальну теми. Варто зазначити, що в цьому році оцінювання студентських робіт було проведене в два етапи спеціальним професійним складом журі. Так, спочатку наукові роботи проходили перевірку на плагіат, а потім уже допускалися до оцінювання такими професіоналами наукової й практичної сфери, як завідувач кафедри цивільного процесу Національного університету «Одеська юридична академія», доктор юридичних наук, професор, заслужений юрист України, адвокат Н.Ю. Голубєва; віце-президент, проректор із наукової роботи Національного університету «Одеська юридична академія», доктор юридичних наук, професор кафедри інтелектуальної власності і корпоративного права Національного університету «Одеська юридична академія» Г.О. Ульянова; суддя, заступник голови Одеського апеляційного суду, кандидат юридичних наук, доцент A.I. Дрішлюк; суддя, голова Київського районного суду м. Одеси, кандидат юридичних наук, доцент C.A. Чванкін; суддя Київського районного суду м. Одеси, кандидат юридичних наук, доцент В.C. Петренко; доктор юридичних наук, професор кафедри європейського та міжнародного права Національного університету «Києво-Могилянська академія» Г.О. Михайлюк; керуючий партнер Юридичної консалтингової компаніі «Де-Юре», адвокат, кандидат юридичних наук, доцент кафедри цивільного процесу Національного університету «Одеська юридична академія» Г.Я. Тріпульський; експерт Громадського центру правосуддя, кандидат юридичних наук, доцент кафедри цивільного процесу Національного університету «Одеська юридична академія» I.O. Бут.

У межах обговорення міжнародних освітніх проектів на телеканалі «Репортер» професор Н.Ю. Голубєва розповіла про новаторські спецкурси, що започатковані та викладаються кафедрою цивільного процесу Національного університету «Одеська юридична академія», зокрема: «Електронне судочинство», «Практика Європейського суду 3 прав людини у цивільному судочинстві», «Розвиток цивільного процесуального права в умовах інтеграційних процесів в Україні», «Європейські стандарти у сфері цивільного судочинства», «Альтернативні засоби захисту цивільних прав».

12 квітня 2019 р. завершальним заходом тижня цивільного процесу став неперевершений, яскравий та улюблений у студентів і викладачів захід - «Фестиваль студентської творчості». Творчий підхід, нестандартні погляди на судову систему й цивільний процес втілилися в різних формах участі студентів: від прекрасних, глибоких віршів до веселих, гумористичних мініатюр. Навіть професійним суддям - народній артистці України, артистці Одеського академічного українського музично-драматичного театру імені В. Василька Діані Малій та переможцю шоу «Розсміши коміка», капітану команди «Пошло-поехало», учаснику «Ліги сміху» Юрію Степанцю - було складно визначитися 3 переможцями серед 16 команд, які змагалися за перемогу та цінний спеціальний приз першого місця - іменний годинник від президента Національного університету «Одеська юридична акаде- 
мія» С.В. Ківалова. Однак у результаті тривалих дискусій і тяжких сумнівів переможці були обрані за підсумками конкурсу та нагороджені пам'ятними подарунками.

19 травня 2019 р. відбулося урочисте закриття тижня цивільного процесу, у ході якого засновниця та ідейний натхненник науково-творчого марафону професор Н.Ю. Голубєва урочисто закрила захід. Із завершальним словом виступили учасники та гості марафону. Так, голова Київського районного суду м. Одеси Чванкін Сергій Анатолійович подякував за запрошення та зауважив, що проведення таких наукових заходів має вагоме значення, оскільки держава переживає складні часи як у судовій системі, так і в юридичній науці загалом. Вшанував своєю присутністю учасників також суддя Київського районного суду м. Одеси B.C. Петренко, постійно діючий журі науково-творчого марафону, який позитивно відгукнувся з приводу ідеї проведення такого заходу. Декан факультету цивільної та господарської юстиції Національного університету «Одеська юридична академія», кандидат юридичних наук, доцент Д.О. Колодін подякував за вкладені зусилля в науково-творчий марафон «Тиждень цивільного процесу» та підкреслив його корисність і цікавість для студентів університету. Керуючий партнер Юридичної консалтингової компаніі «Де-Юре», адвокат, кандидат юридичних наук, доцент кафедри цивільного процесу Національного університету «Одеська юридична академія» Г.Я. Тріпульський подякував за такий яскравий захід та надані студентами цікаві наукові роботи.

Закриття тижня цивільного процесу завершилося підведенням підсумків та урочистим нагородженням студентів за кращі наукові роботи пам'ятними подарунками й дипломами. 